\title{
Public perception of river fish biodiversity in four European countries
}

Sophia Kochalski (1) https://orcid.org/0000-0002-1412-7112, Carsten Riepe (10 http://orcid.org/0000-0002-9148-210X, Marie Fujitani @inttp://orcid.org/0000-0001-5445-7629, Øystein Aas (ํ. http://orcid.org/0000-0003-0688-4049, Robert Arlinghaus (1) https://https://orcid.org/0000-0003-2861-527X

DOI

10.1111/cobi.13180

Original publication date

28 June 2018 (Version of record online)

Document version

Accepted version

Published in

Conservation Biology

\section{Citation}

Kochalski S, Riepe C, Fujitani M, Aas O, Arlinghaus R. Public perception of river fish biodiversity in four European countries. Conservation Biology. 2018. 


\title{
Public perception of river fish biodiversity in four European countries
}

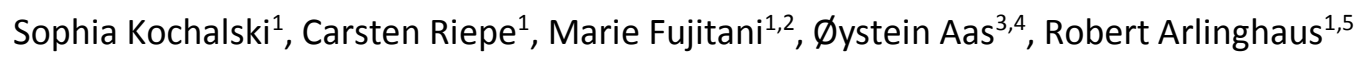

1 Leibniz-Institute of Freshwater Ecology and Inland Fisheries, Müggelseedamm 310, 12587 Berlin, Germany

2 Leibniz Centre for Tropical Marine Research, Fahrenheitstraße 6, 28359 Bremen, Germany

3 Norwegian Institute for Nature Research, Vormstuguvegen 40, 2624 Lillehammer, Norway

4 Norwegian University of Life Sciences, Universitetstunet 3, 1430 Ås, Norway

5 Humboldt-Universität zu Berlin, Unter den Linden 6, 10099 Berlin, Germany

Abstract: Public support for biodiversity conservation is shaped by people's values and their knowledge, beliefs, and attitudes toward the environment. We conducted the first multinational representative survey of the general public's perceptions of river fish biodiversity in France, Germany, Norway, and Sweden. For the online survey, 1000 respondents per country were randomly selected from large panels following country-specific quotas set on age, gender, and educational level. Questions covered people's level of knowledge, beliefs, values, and attitudes toward river fish, environmental threats, and conservation measures. We found that the public had limited knowledge of freshwater fishes. Two nonnative species, rainbow trout (Oncorhynchus mykiss) and brook trout (Salvelinus fontinalis), were widely perceived as native, whereas native Atlantic salmon (Salmo salar) was mostly classified as native in Scandinavia and largely as non-native in central Europe. These results suggest an extinction of experience paralleling the extirpation or decline of salmon stocks in countries such as Germany and France. Respondents thought pollution was the dominant threat to riverine fish biodiversity. In reality, habitat loss, dams, and the spread of non-native fishes are equally important. Despite limited biological knowledge, respondents from all countries held an overwhelmingly pro-ecological worldview, supported conservation stocking, and appreciated native fishes, although only a minority interacted with them directly. Differences among the 4 countries related to several conservation issues. For example, threats to biodiversity stemming from aquaculture were perceived as more prevalent in Norway compared with the other 3 countries. Promoting fish conservation based on charismatic species

This is the peer reviewed version of the following article: Kochalski, Sophia; Riepe, Carsten; Fujitani, Marie; Aas, Øystein; Arlinghaus, Robert. Public perception of river fish biodiversity in four European countries. Conservation Biology 2018 s. $1-12$ which has been published in final form at 10.1111/cobi.13180. This article may be used for non-commercial purposes in accordance with Wiley Terms and Conditions for Use of Self-Archived Versions. 
and use values of fishes may work well in countries with a strong economic and cultural link to the freshwater environment, such as Norway. In countries where people rather abstractly care for nature, focusing conservation messaging on broader ecosystem traits and non-use values of fishes is likely to win more support.

Keywords: attitudes, biodiversity loss, communications, conservation planning, environmental threats, freshwater ecosystems, public opinion, species introduction

\section{Introduction}

The intense use of rivers by humans worldwide has affected riverine biodiversity and freshwater fishes through habitat modification and simplification, water abstraction, alteration of flow regimes, pollution, eutrophication, and local overfishing (Dudgeon et al. 2006). Consequently, species extinction rates in freshwater ecosystems are surpassing those in terrestrial and marine ecosystems (Pimm et al. 2014), with between one quarter and over one-third of freshwater fish species being threatened or extinct in Europe (Freyhof \& Brooks 2011), North America (Jelks et al. 2008), and Africa (Darwall et al. 2011). A prominent example is sturgeon (Acipenser spp.), for which all but 1 species are listed as critically endangered (Freyhof \& Brooks 2011). New threats posed by climate change (Heino et al. 2015) and the invasion of ecosystems by non-native species (Gozlan et al. 2010) will likely increase over the next decades with the potential to further reduce freshwater biodiversity.

Environmental policies introduced to address the freshwater biodiversity crisis are driven and affected by people's priorities and their support for conservation (Walker-Springett et al. 2016). These priorities follow prevailing cultural values and material conditions (Inglehart 1997), meaning they are based on both objectively measurable conditions of the environment and the people's subjective interpretation of nature (Eder 1996). For example, the degree to which people are willing to tolerate wildlife close to their homes is more strongly correlated with the perceived danger from wild animals than with the 
number of dangerous incidents (Kansky \& Knight 2014). In a similar vein, political ideology can be more important for the perception of climate change as environmental threat than scientific descriptions of the phenomenon (Weber 2010). In short, it is the social and cultural context that shapes the mental classification scheme through which an individual and collectively society makes sense of the world; therefore, people in different countries are likely to vary in what they find acceptable, desirable, and important (Schwartz 2006; Manfredo 2008).

Several multi- and cross-national studies have been conducted to examine the impact of sociocultural factors on the public's perception of the marine environment (Ahtiainen et al. 2013; Gelcich et al. 2014; Potts et al. 2016). In comparison, it is less known how the public in different countries perceive freshwater biodiversity (Closs et al. 2015). Based on studies of other environmental issues, the expectations among conservation biologists and fisheries scientists are somewhat bleak. The public is expected to be largely ignorant and complacent about environmental quality and biodiversity loss (Angermeier 2007; Monroe et al. 2009; Closs et al. 2015). People are thought to have a weak connection to freshwater fish and to prefer birds and charismatic mammals (Cooke et al. 2013; Closs et al. 2015) as well as to value direct use of freshwater environments more than biodiversity (Monroe et al. 2009; Beard et al. 2011; Cooke et al. 2013).

Using a cross-cultural online survey, our objectives were to understand whether the members of the public in 4 European countries care about freshwater fishes (values), what people know about fish biodiversity (knowledge), how they view threats to native fish species (beliefs), and what this means for public support for specific conservation measures (attitudes). We used measures of values, knowledge, beliefs, and attitudes following sociopsychological theory that has shown that these constructs play a large role in driving pro-environmental behaviors (Stern 2000; Manfredo 2008; Klöckner 2013). The selection of surveyed countries was based on the study's interest for charismatic migratory fish species. We surveyed 2 central European countries - Germany and France - where rivers are heavily altered by humans and Atlantic salmon (Salmo salar) has been extirpated (Germany) or is rare (France), and 2 non-commercial purposes in accordance with Wiley Terms and Conditions for Use of Self-Archived Versions. 
Scandinavian countries - Norway and Sweden - where Atlantic salmon is still present. We also assumed the 4 countries differ in how the public uses and interacts with freshwater ecosystems. Taking recreational fishing as an example activity, previous research suggests the 4 countries form clusters of low (Germany, 4.0\%; France, 8.2\%) and high recreational use (Norway, 32.2\%; Sweden, 23.0\%) (Arlinghaus et al. 2015).

\section{Methods}

\section{Survey administration and sampling}

The survey was administered over the internet in September 2015 using large, high-quality online panels with 40,000-100,000 members/country. Panel members were recruited previously by phone with a random digit-dialing method as sampling frame. This probability-based approach to panel recruitment avoids the self-selection bias of nonrandom consumer panels that rely on voluntary participants (opt-in panels) (Baker et al. 2010). To avoid respondent fatigue, panel members are invited to participate in a survey at a maximum of 6 times/year.

Respondents were randomly selected from the panels and invited via email to participate in the survey. Up to 3 reminder emails were sent during the survey period of 21 days. Data collection conformed to the rules given by the national Data Protection Acts as well as standards for social research as outlined by the European Society for Opinion and Market Research (ESOMAR \& GRBN 2015; ICC \& ESOMAR 2016). The sample selection followed country-specific quotas set on age groups, gender, and the highest education level achieved according to census data (Eurostat 2015). We removed 287 respondents from the sample with implausibly low response times (speeding), 3 respondents who gave the same answers in more than 3 grids (straight lining), and respondents who answered $<20 \%$ of all questions (item nonresponse) (Groves et al. 2011). Aside from these cases of potentially fraudulent or 
inattentive participants, 4844 persons started the questionnaire. Overall, $17.4 \%(n=844)$ of the initial sample quit participating.

The final sample of 1000 respondents/country, aged 16 to 74 years, approximated a representative sample relative to the previously defined quota characteristics. Further respondent characteristics are described in Supporting Information. We defined our study population as the general population with internet access, which covered from $83 \%$ (France) to $97 \%$ (Norway) of all private households (Germany, 90\%; Sweden, 91\%) (Eurostat 2016). In December 2016, 61\% of the respondents took part in a follow-up survey of which one question about Atlantic salmon was relevant for this study.

\section{Survey questions}

The 2015 questionnaire covered human values and the value of native fish populations; self-reported and revealed knowledge; beliefs about environmental threats; and attitudes toward conservation and management measures. The assumption that the countries would differ in relation to outdoor activities bound to water was verified by asking respondents about their recreational activities (Supporting Information). In 2016, respondents were surveyed again and asked whether they thought that salmon and Atlantic salmon were native to 6 European countries, including their own. All questions were worded using neutral and accessible language. The questions were pretested with experts in freshwater ecology and members of the public. The final survey was translated professionally into German, French, Norwegian (Bokmål), and Swedish. Pilot interviews $(n=4 \times 30)$ resulted in only minor adaptations of the questionnaire.

Environmental values were measured with 3 items from the Schwartz (2012) value scale (e.g., "respecting the earth, living in harmony with other animal and plant species") using a 5-point response format (1, not at all important, to 5 , very important). Cronbach's reliability coefficient for this scale was high $(\alpha=0.89$ ). See Supporting Information for the scale's item wording. The use and non-use values of native fish populations were assessed (from 1, strongly disagree, to 5, strongly agree) using 6 items 
adapted from ecosystem valuation frameworks (Hein et al. 2006) (e.g., "Native fish populations should be protected for their own sake").

Concerning knowledge about native biodiversity and threats from non-native fishes, respondents were asked for a self-assessment (1, not informed at all, to 4 , very well informed). Familiarity with river fish species was assessed by presenting the respondents with 3 native freshwater (brown trout [Salmo trutta], grayling [Thymallus thymallus], and bream [Abramis brama]), 2 non-native salmonids (rainbow trout [Oncorhynchus mykiss] and brook trout [Salvelinus fontinalis]), and 3 native diadromous species (Atlantic salmon, sturgeon, and European eel [Anguilla anguilla]). In Scandinavia, sturgeon is only native to the south. Another species, barbel (Barbus barbus), is a key species for the fish-based zonation of rivers in central Europe, but is not native to Scandinavia. Respondents were asked whether they had heard of the species and, if they answered affirmatively, whether they thought the species was native to the inland waters of their country.

People also rated the contribution of 5 threats to fish biodiversity loss (1, no contribution at all, to 4 , a very strong contribution). The items reflected major threat categories for freshwater biodiversity (Dudgeon et al. 2006). Attitudes toward conservation and management actions were assessed based on 10 items ranked in a 5-point response format (1, very bad, to 5, very good). The items represented factual information about non-native fish species, stocking as a common practice in fisheries management, and coastal aquaculture.

\section{Data analysis}

We used factor analysis with orthogonal Varimax rotation to structure our data and identify indicator items of underlying latent constructs for the established Schwartz value scale. We used principal component analysis to reduce correlated observed attitude items to a smaller set of composite scores. Items with high loadings on the same factor were aggregated to form composite scores as measures of these constructs. Individual items and composite scores that were collected on Likert-type rating scales 
were analyzed for country differences using the Kruskal-Wallis test and the Tukey-Kramer (Nemenyi) test for pairwise post hoc comparisons. The familiarity with native and non-native fish species was compared between countries with Pearson's chi-squared tests. All data were analyzed with R version 3.2.2.

\section{Results}

\section{Environmental values and the value of native fish populations}

Basic environmental values were assessed with 3 items representing one construct ( $73 \%$ explained variance); it was labeled harmony with nature. This construct was rated, on average, as important in all 4 countries. However, for Norwegians $(n=1000, M=3.6, S D 0.9)$ followed by the French $(n=1000, M=$ 3.8, SD 0.9) achieving harmony with nature was slightly less important than for the respondents in Germany $(n=995, M=3.9, S D 0.9)$ and Sweden $(n=999, M=3.9$, SD 0.9). This difference was statistically significant (Kruskal-Wallis $H=75.3, \mathrm{df}=3, p<0.001$ ).

Coinciding with their values, respondents in all countries highly appreciated native fish populations for their non-use value and less so for their use value (Table 1). The French agreed significantly less than the other countries with the importance of the existence value $(H=61.9, \mathrm{df}=3, p<0.001)$ and bequest value $(H=53.6, \mathrm{df}=3, p<0.001)$ of native fish populations. Norwegians appreciated native fish populations not only for their non-use but also for the use value that fish bring to humans (Table 1). In comparison to other countries, Norwegians also disagreed most strongly with the idea that they would not personally benefit from the protection of native fish populations (option value: $H=264, \mathrm{df}=3, p<$ 0.001), and they agreed most strongly with the need to preserve fish populations for the benefits of others (altruistic value; $H=700, \mathrm{df}=3, p<0.001$ ). French respondents, on average, expressed stronger use values relative to the other 3 countries (Table 1). The other respondents, particularly the Germans and Swedes, tended to disagree on average with the direct-use value of native fish populations for the non-commercial purposes in accordance with Wiley Terms and Conditions for Use of Self-Archived Versions. 
(Table 1).

Table 1. Mean (SD) approval (1, strongly disagree, to 5, strongly agree) of survey respondents from 4 countries to protect native fish populations for their non-use (existence and bequest value) or use values (direct use, option and altruistic value). . $^{a, c, d}$

\begin{tabular}{|c|c|c|c|c|c|c|}
\hline Value category & Survey item & Germany & France & Norway & Sweden & $H^{e}$ \\
\hline Existence value & $\begin{array}{l}\text { Native fish populations } \\
\text { should be protected } \\
\text { for their own sake. }\end{array}$ & $4.2 \mathrm{a}(0.8)$ & $4.0 c(0.9)$ & $4.1 b(1.0)$ & $4.0 \mathrm{bc}(0.9)$ & 61.9 \\
\hline Bequest value & $\begin{array}{l}\text { I think it is good to } \\
\text { preserve native fish } \\
\text { populations to } \\
\text { maintain an } \\
\text { environment worth } \\
\text { living in for our } \\
\text { children and future } \\
\text { generations. }\end{array}$ & 4.3a (0.8) & $4.1 b(0.9)$ & 4.3a (0.9) & 4.3a (0.9) & 53.6 \\
\hline Altruistic value & $\begin{array}{l}\text { Native fish populations } \\
\text { should primarily be } \\
\text { preserved for the } \\
\text { benefit of others. }\end{array}$ & $2.6 \mathrm{~d}(1.2)$ & $3.3 b(1.0)$ & 3.9a (1.0) & $2.8 \mathrm{c}(1.1)$ & 700 \\
\hline Option value & $\begin{array}{l}\text { I wouldn't benefit in any } \\
\text { way from the } \\
\text { protection and } \\
\text { conservation of native } \\
\text { fish populations. } f\end{array}$ & $3.3 b(1.2)$ & $3.1 a(1.0)$ & $3.8 c(1.2)$ & $3.1 \mathrm{a}(1.2)$ & 264 \\
\hline \multirow[t]{2}{*}{ Direct use value } & $\begin{array}{l}\text { Native fish populations } \\
\text { should primarily be } \\
\text { managed for human } \\
\text { benefit. }\end{array}$ & $2.5 d(1.1)$ & $3.2 \mathrm{a}(1.2)$ & $2.9 b(1.2)$ & $2.7 c(1.2)$ & 186 \\
\hline & $\begin{array}{l}\text { Native fish populations } \\
\text { are valuable only if I } \\
\text { get to use them in } \\
\text { some way. }\end{array}$ & $2.0 b(1.0)$ & $2.6 a(1.2)$ & $1.9 c(1.0)$ & $2.0 \mathrm{~b}(1.1)$ & 297 \\
\hline $\begin{array}{l}\text { Number of } \\
\text { observations }\end{array}$ & & 998 & 998 & 998 & 992 & \\
\hline
\end{tabular}

\section{Self-reported and revealed knowledge related to fish biodiversity}

A large majority of the respondents stated that they did not feel well informed about fish biodiversity

(86\%). Norwegians felt, on average, significantly better informed about fish biodiversity $(H=1$

This is the peer reviewed version of the following article: Kochalski, Sophia; Riepe, Carsten; Fujitani, Marie; Aas, Øystein; Arlinghaus, Robert. Public perception of river fish biodiversity in four European countries. Conservation Biology 2018 s. $1-12$ which has been published in final form at 10.1111/cobi.13180. This article may be used for non-commercial purposes in accordance with Wiley Terms and Conditions for Use of Self-Archived Versions. 

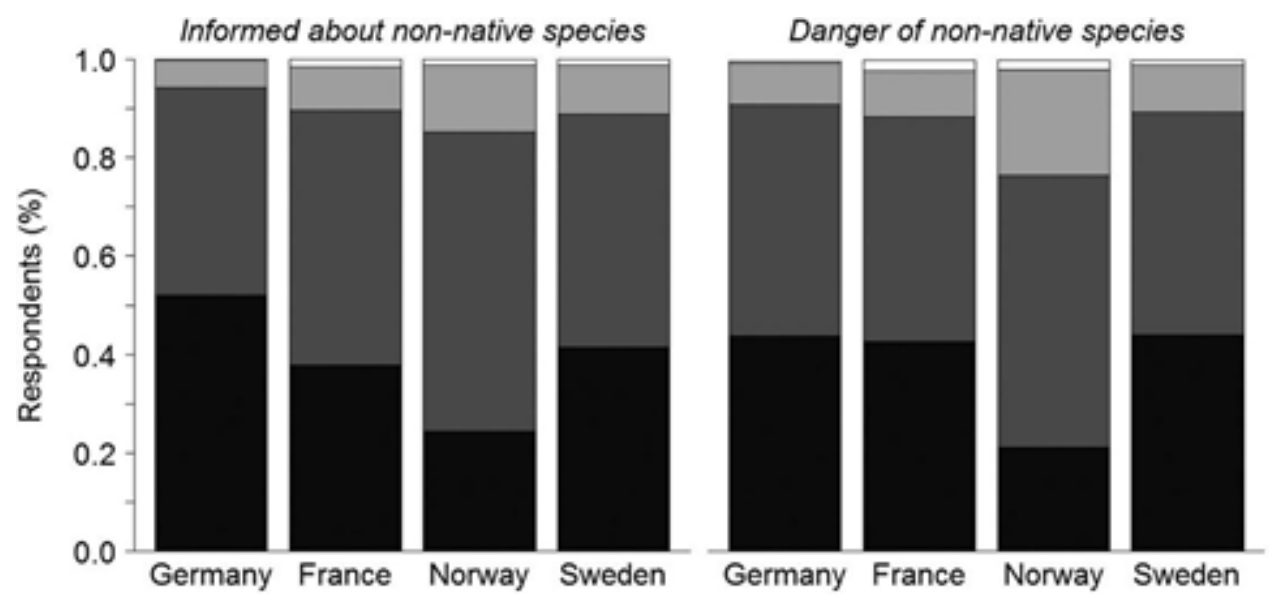

Figure 1. Self-reported level of feeling informed about fish biodiversity $(n=4000)$ and the threats caused by the introduction of non- native fish species ( $n=3991$ ) (black, not informed at all; dark gray, not well informed; light gray, well informed; white, very well informed).

Over $85 \%$ of the respondents in Germany, Sweden, and Norway indicated they had heard of the salmonids brown trout and rainbow trout, whereas in France, these species were significantly less known (brown trout: 64\%; rainbow trout: 70\%). Two other salmonids, brook trout and grayling, were less well known overall (Fig. 2). Atlantic salmon and the other diadromous fishes in the surveysturgeon and European eel - were recognized in the 2015 survey by at least $85 \%$ (salmon, eel) and at least 79\% (sturgeon) of the respondents. Atlantic salmon and European eel were well known in Norway and Sweden (>96\%), but significantly less so in France (81\%) and Germany (58\%). In contrast, sturgeon was significantly better known in Germany (92\%) and France (84\%) than in Norway (65\%) and Sweden (76\%). The same was true for the cyprinid barbel, which was recognized by less than $5 \%$ of respondents in the Scandinavian countries, but by about half of the respondents in Germany and France (Fig. 2). Bream was recognized by half of the respondents in Germany, France, and Norway, and by $85 \%$ of the Swedish respondents (Fig. 2).

When a respondent indicated familiarity with a fish species, the next question asked whether the respondent believed the fish species was native or non-native. Rainbow trout and brook trout -2

This is the peer reviewed version of the following article: Kochalski, Sophia; Riepe, Carsten; Fujitani, Marie; Aas, $\emptyset$ ystein; Arlinghaus, Robert. Public perception of river fish biodiversity in four European countries. Conservation Biology 2018 s. 1-12 which has been published in final form at 10.1111/cobi.13180. This article may be used for non-commercial purposes in accordance with Wiley Terms and Conditions for Use of Self-Archived Versions. 
(Fig. 2). Two native migratory fish species, Atlantic salmon and sturgeon, were perceived by only $40 \%$ of
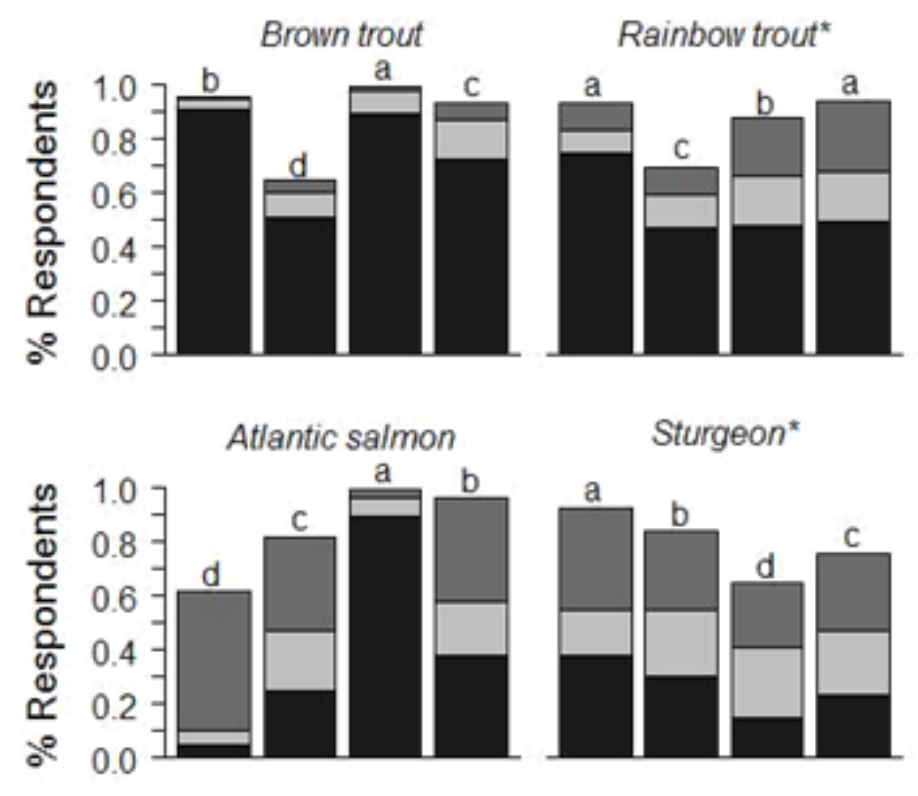

\section{Brook trout ${ }^{*}$}

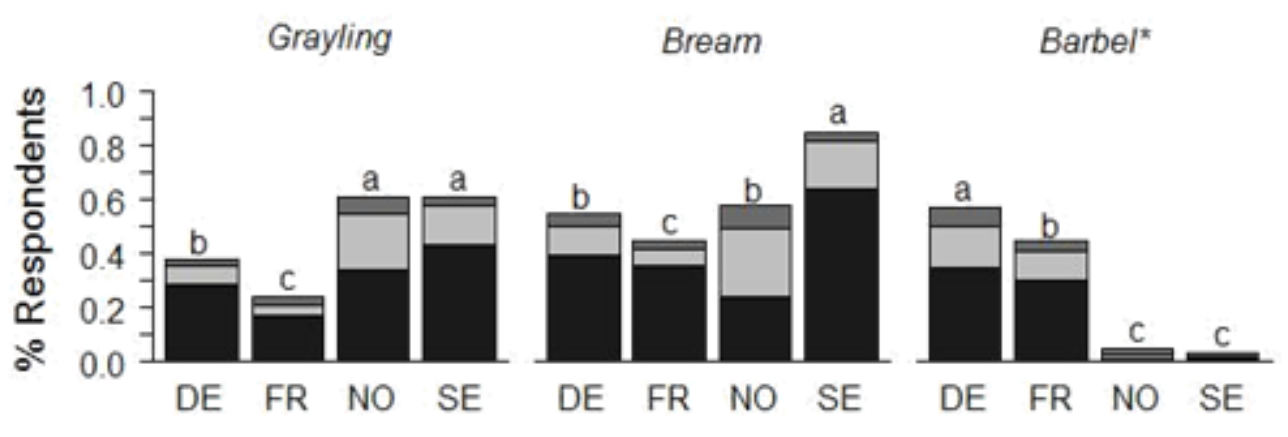

Figure 2. Familiarity of 1000 respondents in Germany (DE), France (FR), Norway (NO), and Sweden (SE) with fish species (1, familiar; 0 , unfamiliar) and their perceived native* or non-native origin to inland waters (black, native; light gray, unsure or don't know; dark gray, not native) ( species not native to all, some, or parts of the 4 countries). Differences between countries for the familiarity with fish species were tested for significance with the Kruskal-Wallis test. Any 2 bars that do not share a letter are significantly different $(p<0.05)$ according to pairwise comparisons made with the Tukey-Kramer (Nemenyi) test.

A follow-up question that was asked in 2016 showed that respondents from all countries associated salmon with the Scandinavian countries Norway (82-97\% of respondents) and Sweden (77-92\%), but to

This is the peer reviewed version of the following article: Kochalski, Sophia; Riepe, Carsten; Fujitani, Marie; Aas, $\emptyset$ ystein; Arlinghaus, Robert. Public perception of river fish biodiversity in four European countries. Conservation Biology 2018 s. 1-12 which has been published in final form at 10.1111/cobi.13180. This article may be used for non-commercial purposes in accordance with Wiley Terms and Conditions for Use of Self-Archived Versions. 
although in reality, Atlantic salmon is native to all 6 countries. This pattern remained the same when asking about Atlantic salmon rather than salmon (Table 2). In comparison with salmon, more people believed Atlantic salmon to be native in France (32-59\% of respondents across countries) and Spain (21$26 \%)$, and fewer people believed it to be native in Norway (78-95\%), Sweden (56-74\%), Germany (18$35 \%)$, and the Czech Republic (6-21\%).

Table 2. Percentage of survey respondents $a$ in Germany $(n=642)$, France $(n=578)$, Norway $(n=500)$, and Sweden $(n=586)$ who perceived salmon and Atlantic salmon as native in 6 European countries (Czech Republic [CZ], France [FR], Germany [DE], Norway [NO], Spain [ES], and Sweden [SE]).

\begin{tabular}{|c|c|c|c|c|c|c|c|c|c|c|c|c|}
\hline \multirow[b]{2}{*}{ Respondent country } & \multicolumn{6}{|c|}{ Salmon native to country } & \multicolumn{6}{|c|}{ Atlantic salmon native to country } \\
\hline & $C Z$ & $F R$ & $D E$ & NO & ES & $S E$ & $C Z$ & $F R$ & $D E$ & NO & ES & $S E$ \\
\hline Germany & 30 & 32 & 58 & 96 & 8 & 92 & 8 & 42 & 29 & 87 & 24 & 74 \\
\hline France & 33 & 61 & 44 & 82 & 27 & 77 & 21 & 59 & 31 & 78 & 26 & 72 \\
\hline Norway & 36 & 40 & 51 & 97 & 29 & 92 & 11 & 32 & 35 & 95 & 23 & 70 \\
\hline Sweden & 28 & 28 & 34 & 94 & 18 & 92 & 6 & 36 & 18 & 88 & 21 & 56 \\
\hline
\end{tabular}

a Most of the data presented in this study was obtained in 2015. The information underpinning this table was obtained during a follow-up survey in 2016.

\section{Beliefs about environmental threats to riverine fishes}

With regard to environmental threats, respondents in all 4 countries believed that water pollution

This is the peer reviewed version of the following article: Kochalski, Sophia; Riepe, Carsten; Fujitani, Marie; Aas, Øystein; Arlinghaus, Robert. Public perception of river fish biodiversity in four European countries. Conservation Biology 2018 s. $1-12$ which has been published in final form at 10.1111/cobi.13180. This article may be used for non-commercial purposes in accordance with Wiley Terms and Conditions for Use of Self-Archived Versions. 

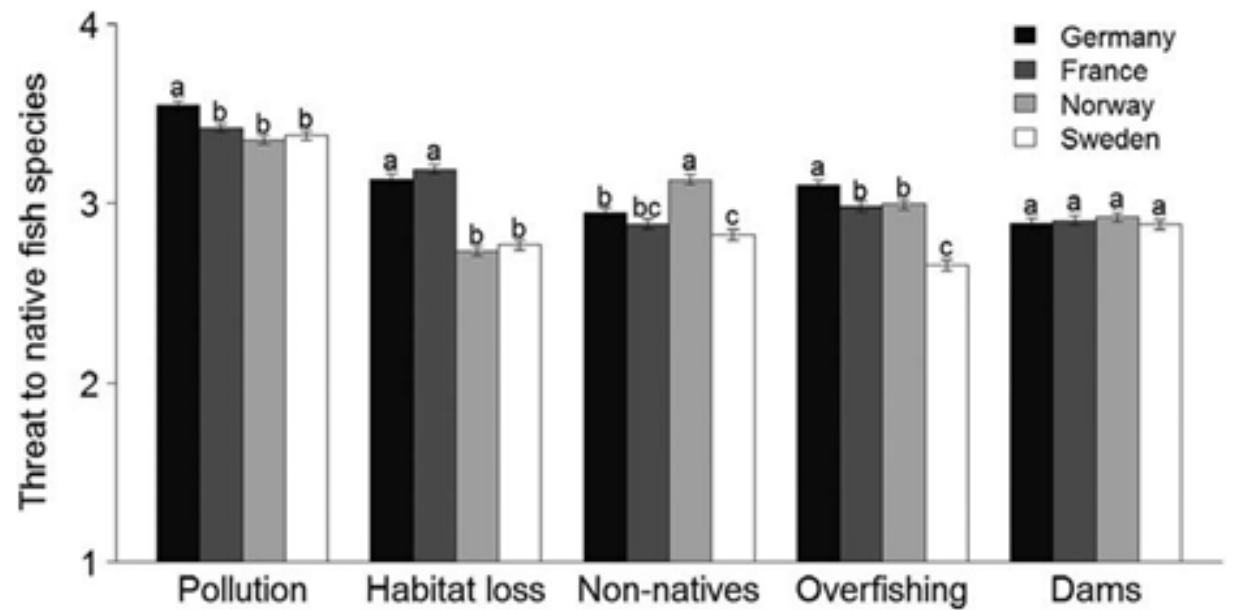

Figure 3. Mean (SE) survey respondents' perceived degree to which water pollution, loss of natural river bank habitat, introduction of non-native species of plants and animals, including fishes, to rivers by humans, overfishing, and the construction of dams for hydroelectric power generation threaten native fish species in Germany $(n=898)$, France $(n=831)$, Norway $(n=809)$, and Sweden $(n=789)(1$, no contribution at all, to 4, very strong contribution). Differences between countries were tested for significance with the Kruskal-Wallis test. Any 2 means for each threat that do not share a letter are significantly different $(p<0.05)$ according to pairwise comparisons made with the Tukey-Kramer (Nemenyi) test.

\section{Attitudes toward fish conservation and management measures}

The reestablishment of Atlantic salmon and sturgeon to rivers where they had been extirpated through human influence was supported in all 4 countries, and the approval was significantly highest in Germany $(H=312, \mathrm{df}=3, p<0.001 ;$ Table 3). Culture-based enhancement stocking of rainbow trout and brook trout (both non-native species) for fisheries purposes received less support than conservation stocking of Atlantic salmon and sturgeon; however, people did also not oppose it on average (Table 3). In Germany, culture-based stocking of brook trout and rainbow trout was viewed more positively relative to the other 3 countries $(H=295, \mathrm{df}=3, p<0.001)$.

Table 3. Mean (SD) attitudes (1, very bad, to 5 , very good) of survey respondents from 4 countries toward conservation stocking ( 2 items), culture-based enhancement stocking ( 3 items), aquaculture management ( 3 items), and the biodiversity risk of aquaculture ( 2 items) ${ }^{a, b, c, d}$

\begin{tabular}{lcccccc}
\hline Survey item & Loading & Germany & France & Norway & Sweden & $H e$ \\
\hline Conservation stocking & & & & & & \\
Sturgeon are being reintroduced by & 0.904 & $4.2 \mathrm{a}(0.8)$ & $3.7 \mathrm{~b}(1.0)$ & $3.4 \mathrm{c}(1.1)$ & $3.6 \mathrm{c}(1.0)$ & 330
\end{tabular}

This is the peer reviewed version of the following article: Kochalski, Sophia; Riepe, Carsten; Fujitani, Marie; Aas, Øystein; Arlinghaus, Robert. Public perception of river fish biodiversity in four European countries. Conservation Biology 2018 s. $1-12$ which has been published in final form at 10.1111/cobi.13180. This article may be used for non-commercial purposes in accordance with Wiley Terms and Conditions for Use of Self-Archived Versions. 
stocking to some European waters where they were native and extirpated through human influence.

Atlantic salmon are being reintroduced by stocking to some European rivers where they were native and extirpated through human influence.

\section{Culture-based stock enhancement}

At the end of the 19th century, brook trout and rainbow trout were deliberately introduced from North America as edible fishes to the rivers of (insert country).

Some nature conservationists demand that non-native brook trout and rainbow trout be extirpated from the rivers in (insert country) to protect the native species biodiversity. $f$

Fisheries managers release hatchery-bred brook trout and rainbow trout into the wild to increase fisheries catch.

\section{Aquaculture management}

Rainbow trout raised in fish farms can be made infertile by thermal treatment of eggs. As a result they achieve a higher slaughter weight.

It is possible to intentionally alter the expression of specific genes of salmon and trout to achieve a higher slaughter weight.

Across Europe, Atlantic salmon and rainbow trout are often bred in net cages placed in coastal zones or in fish farms on land for human consumption.

\section{Biodiversity risk of aquaculture}

Sometimes Atlantic salmon and rainbow trout unintentionally escape from fish farms into the wild and then interbreed with their wild conspecifics.

Sometimes Atlantic salmon and rainbow trout unintentionally escape from fish farms into the wild and then transmit parasites or diseases to their wild conspecifics. orthogonal rotation.

${ }^{f}$ Scoring reversed because of negatively worded item.
0.899

$4.1 \mathrm{a}(0.8) \quad 3.6 \mathrm{~b}(1.0)$

$3.6 \mathrm{~b}(1.1)$

$3.6 b(1.0)$

217

$\begin{array}{cccccc}- & 3.3 a(0.9) & 2.7 d(1.0) & 2.9 c(0.9) & 3.0 b(0.9) & 295 \\ 0.742 & 3.2 \mathrm{a}(0.8) & 3.0 \mathrm{~b}(0.9) & 3.0 \mathrm{~b}(0.9) & 3.2 \mathrm{a}(0.8) & 60.7\end{array}$

$3.4 a(0.9)$

$2.5 c(0.9)$

$2.9 b(0.9)$

$2.8 b(0.9)$

474

3.1a (0.9)

$2.7 c(1.0)$

$2.8 \mathrm{bc}(1.0)$

$2.9 b(1.0)$

- $\quad 2.2 c(1.0)$

$2.4 a b(1.1)$

$2.5 a(1.1)$

$2.4 b(1.0)$

112

0.860

$2.0 d(0.9)$

$2.3 \mathrm{~b}(1.0)$

2.5a (1.0)

$2.2 \mathrm{c}(1.0)$

143

0.795

$1.7 b(0.9)$

2.2a (1.0)

$2.2 \mathrm{a}(1.0)$

2.1a (1.0)

135

0.585

$2.8 \mathrm{ab}$ (1.0)

$2.8 \mathrm{ab}(1.1)$

2.9a (1.0)

14.9

$\begin{array}{cccccc}- & 2.1 b(0.9) & 2.4 a(1.1) & 1.7 d(0.8) & 2.0 c(0.9) & 442 \\ 0.861 & 2.6 a(0.8) & 2.7 a(1.0) & 1.9 c(0.9) & 2.5 b(0.9) & 488\end{array}$

0.784 $1.6 b(0.7)$ 2.0a (1.0)

$1.4 c(0.7)$

$1.6 b(0.8)$ 201

$a, b, c, d$ Any 2 means in a row that do not share a letter are significantly different $(p<0.05)$ according to pairwise comparisons made with the Tukey-Kramer (Nemenyi) test. Survey items grouped by principal component analysis with Varimax

${ }^{e}$ Differences between countries tested for statistical significance with the Kruskal-Wallis test.

This is the peer reviewed version of the following article: Kochalski, Sophia; Riepe, Carsten; Fujitani, Marie; Aas, $\emptyset$ ystein; Arlinghaus, Robert. Public perception of river fish biodiversity in four European countries. Conservation Biology 2018 s. 1-12 which has been published in final form at 10.1111/cobi.13180. This article may be used for non-commercial purposes in accordance with Wiley Terms and Conditions for Use of Self-Archived Versions. 
Respondents in all countries felt rather negative toward escapees from aquaculture (Table 3). Despite this concern, respondents did not support the treatment of farmed fish that could render the fish infertile, thus reducing the genetic risks associated with escapees. Norwegians felt significantly more positive toward these aquaculture management measures $(H=112, \mathrm{df}=3, p<0.001)$ and significantly more negative toward escapees from aquaculture $(H=442, \mathrm{df}=3, p<0.001)$ than the public in the other 3 countries. Despite being more concerned about the associated risks, Norwegian respondents did not have a more negative attitude toward aquaculture than the other 3 nations (Table 3).

\section{Discussion}

Most of the previous social science studies on freshwater fish and biodiversity have been conducted on specific stakeholder groups and single countries (Bremner \& Park 2007; Riepe \& Arlinghaus 2014; Walker-Springett et al. 2016). Our study broadens the perspective in relation to the public's perception of river fish biodiversity in central and northern Europe using identical questionnaires. Cross-national studies, such as ours, shed light on which perceptions are confined to or shared by single countries or cultures. We found that the publics of our 4 countries shared high levels of pro-environmental concern, positive attitudes toward fish conservation, and limited knowledge about biological realities under water. But we also found important differences in the beliefs and attitudes reflecting national specificities.

\section{General patterns held across countries}

The public in all 4 countries valued native fish species for their existence (Table 1) and supported conservation stocking (Table 3). These findings coincided with the predominantly pro- environmental values of the public. Modernization and postindustrialization have resulted in a rise of abstract proenvironmental values within many wealthy societies (Inglehart 1990, 1997) and fostered the cultural value of egalitarianism, broadly defined as the desire to take care of the well-being of fellow humans, but also animals and the environment (Schwartz 2006). In this study, people cared about fish

This is the peer reviewed version of the following article: Kochalski, Sophia; Riepe, Carsten; Fujitani, Marie; Aas, $\emptyset$ ystein; Arlinghaus, Robert. Public perception of river fish biodiversity in four European countries. Conservation Biology 2018 s. 1-12 which has been published in final form at 10.1111/cobi.13180. This article may be used for noncommercial purposes in accordance with Wiley Terms and Conditions for Use of Self-Archived Versions. 
conservation in a positive way, likely because this animal group was perceived as part of nature that they felt should be protected. We would expect to find similar results in other western European countries featuring high scores in egalitarian cultural values (Schwartz 2006). However, there is the limitation that we did not study the relative importance of different taxa or ecosystem characteristics, such as water quality (Hanley et al. 1998). Further studies on the perceptions of freshwater fishes in countries with other national value priorities (Schwartz 2006) and on people's preferences for various ecosystem traits are needed to fully understand the values underlying freshwater fish conservation.

The self-reported level of knowledge of river fish biodiversity was low in all 4 countries (Fig. 1), in line with the expectations expressed in the scientific literature (Monroe et al. 2009; Cooke et al. 2013; Closs et al. 2015). Well-known species included both native (e.g., brown trout) and non- native (e.g., rainbow trout) salmonids, but there were also native (e.g., grayling) and non-native (e.g., brook trout) salmonids that were less well known (Fig. 2). Respondents were familiar with migratory fish, such as sturgeon and Atlantic salmon, but were less certain about these species' range of natural occurrence. It is highly likely that this pattern represents an example of an "extinction of experience" (Miller 2005) because, for example, Atlantic salmon were extirpated from Germany in the mid-20th century (Wolter 2015) and its abundance declined greatly in other European countries (Chaput 2012). Given that all surveyed countries showed that loss of memory with regard to the situation in their own or other countries (Table 2), we would expect similar results for other European countries.

Relative to environmental threats, the respondents perceived pollution to pose the biggest threat to freshwater biodiversity (Fig. 3), possibly remembering high level of discernible pollution in the 1960s and 1970s. Since then water quality has improved across many rivers due to advances in water purification and the implementation of the European Water Framework Directive (Directive 2000/60/EC). Our results parallel findings for the marine environment where pollution was also perceived to be the dominant threat in many different countries (Gelcich et al. 2014; Potts et al. 2016), possibly because of the high media coverage of marine pollution events. Similar incidents in the freshwater environment date back

This is the peer reviewed version of the following article: Kochalski, Sophia; Riepe, Carsten; Fujitani, Marie; Aas, $\emptyset$ ystein; Arlinghaus, Robert. Public perception of river fish biodiversity in four European countries. Conservation Biology 2018 s. 1-12 which has been published in final form at 10.1111/cobi.13180. This article may be used for noncommercial purposes in accordance with Wiley Terms and Conditions for Use of Self-Archived Versions. 
decades (Reinhard 2008), but recent media campaigns on plastic waste, micro-pollutants, and microplastics could have had an impact on public perception. For river conservation, it will be important to increase people's awareness about less visible threats (Dudgeon et al. 2006; Gozlan et al. 2010; Freyhof \& Brooks 2011).

\section{Country-specific patterns}

Norwegians felt better informed and were more concerned about non-native species (Figs. 1 \& 3) and biodiversity risks from aquaculture farms than the members of the public in the other countries (Table 3). This may be related to the debate about the expanding salmon aquaculture industry in Norway and its significant media coverage (Olsen \& Osmundsen 2017). Through escapees and introgression of aquaculture genotypes into wild stocks, there is evidence that farmed salmon have had direct and indirect negative impacts on wild salmon populations (Bolstad et al. 2017). Despite being more concerned with risks, Norwegian respondents did not have a more negative attitude toward aquaculture than the other nations (Table 3), possibly trading off the biodiversity risks related to aquaculture against the economic benefits to Norwegian society.

The use value of fish populations was seen as less important than their non-use value in Germany and Sweden compared with Norway (Table 1), where fish and fisheries are important for recreational and commercial purposes (Borch et al. 2008; Arlinghaus et al. 2015). Despite low use values, Germany evaluated culture-based stocking comparatively positive (Table 3), possibly because brook trout and rainbow trout are legally considered to be native and intensively stocked into German waters (Arlinghaus et al. 2015) seemingly with limited ecological impacts (Wolter \& Röhr 2010). An interesting case is France, where the public expressed a comparably high use value and a lower importance of the non-use values bequest and existence. In cross-cultural studies, France showed less egalitarian cultural values compared with the other 3 countries, and it scored higher on intellectual autonomy as cultural value (Schwartz 2006). This may explain why the instrumental use value of fish populations was larger in France compared with the other 3 countries. Overall, country-specific factors were more important for This is the peer reviewed version of the following article: Kochalski, Sophia; Riepe, Carsten; Fujitani, Marie; Aas, $\varnothing$ ystein; Arlinghaus, Robert. Public perception of river fish biodiversity in four European countries. Conservation Biology 2018 s. 1-12 which has been published in final form at 10.1111/cobi.13180. This article may be used for noncommercial purposes in accordance with Wiley Terms and Conditions for Use of Self-Archived Versions. 
explaining use values than non-use values, because western Europeans share high levels of environmental values (Schwartz 2006), but differ with regard to other value dimensions, have differently structured economies, and different preferences with regard to recreation and food (EUMOFA 2017).

\section{Implications for fish conservation}

Human behavior is complex and multifaceted. It is informed by a person's psychological disposition as well as by situational and contextual factors (Stern 2005; Steg \& Vlek 2009). Psychological constructs (such as knowledge, values, beliefs, and attitudes) do not always translate into action (Kollmuss \& Agyeman 2002), but they can be important drivers of pro-environmental behavior when the contextual factors are favorable (Stern 2000, 2005; Riepe et al. 2017). Given that we did not observe actual behavior, we limit our conclusions for fish conservation to implications for conservation messaging.

Conservation messaging can achieve behavioral change, especially when combined with other interventions (Osbaldistan \& Schott 2012). Our results suggest that public outreach campaigns promoting fish conservation based on use values may not be effective in those European countries where society cares abstractly about fishes and considers overfishing to be a key reason for population declines (e.g., in Germany). Threat-related messages with the purpose of increasing support for aquatic conservation measures are well known from the marine environment (e.g., campaigns focusing on bycatch or marine litter) but are currently limited in the freshwater context due to misconceptions of the public (as seen in this study) and the complexity of interacting threats (Dudgeon et al. 2006; Cooke et al. 2013). Instead, focusing messaging on broader ecosystem traits (e.g., unpolluted and free-flowing water) that will indirectly help extirpated or threatened riverine species recover is likely to win more public support.

A new approach to freshwater conservation is concentrating conservation messages on charismatic species (Carrizo et al. 2017; Kalinkat et al. 2017), such as migratory fish (Bolster 2008; Kalinkat et al. 2017). This approach may be effective in countries where the public has a connection to a species (e.g., Atlantic salmon in Norway). For central Europe, we found the situation was more complex: the general This is the peer reviewed version of the following article: Kochalski, Sophia; Riepe, Carsten; Fujitani, Marie; Aas, Øystein; Arlinghaus, Robert. Public perception of river fish biodiversity in four European countries. Conservation Biology 2018 s. 1-12 which has been published in final form at 10.1111/cobi.13180. This article may be used for noncommercial purposes in accordance with Wiley Terms and Conditions for Use of Self-Archived Versions. 
public supported conservation stocking despite not recognizing the species. This finding suggests knowledge is not essential for conservation support, but what matters are pro-ecological beliefs and attitudes (Manfredo et al. 2017). We suggest enhancing the connection between native fish biodiversity and the general public by involving groups, such as anglers, that directly interact with the aquatic environment (Fujitani et al. 2017), as well as historians and artists who can highlight historical relationships with native fish species (Rathwell \& Armitage 2016), in conservation research and outreach activities.

\section{Acknowledgements}

This project received funding from the German Research Foundation within the project Salmolnvade in the BiodivERsA 2012-2013 Pan-European call (grant AR 712/4-1) and from the European Union's Horizon 2020 research and innovation program under the Marie Sklodowska-Curie project IMPRESS (grant 642893). Funding in Germany was also received from the German Federal Ministry of Education and Research (BMBF) to R.A. within the project Besatzfisch (grant 01UU0907) in the Programme for Social-Ecological Research. We thank D. Behr, J. Cucherousset, J. Johnsson, K. Hindar, and all other members of the Salmolnvade project and the team of Language Connect for their support related to the translation of the questionnaire. We give our special thanks to F. Funke, M. Reich, A. Wachenfeld, and all other people of LINK and Norstat for collecting the data and to all participants for their cooperation.

\section{Supporting information}

Respondents' characteristics (Appendix S1), details for the Schwartz value scale (Appendix S2), the recreational activities respondents performed in the 12 months prior to the survey (Appendix S3), and the survey questions (Appendix S4) are available online. The authors are solely responsible for the

This is the peer reviewed version of the following article: Kochalski, Sophia; Riepe, Carsten; Fujitani, Marie; Aas, $\varnothing$ ystein; Arlinghaus, Robert. Public perception of river fish biodiversity in four European countries. Conservation Biology 2018 s. 1-12 which has been published in final form at 10.1111/cobi.13180. This article may be used for noncommercial purposes in accordance with Wiley Terms and Conditions for Use of Self-Archived Versions. 
content and functionality of these materials. Queries (other than absence of the material) should be directed to the corresponding author.

\section{Literature cited}

Ahtiainen H, et al. 2013. Public preferences regarding use and condition of the Baltic Sea - An

international comparison informing marine policy. Marine Policy 42, 20-30.

Angermeier PL. 2007. The role of fish biologists in helping society build ecological sustainability.

Fisheries 32(1), 9-20.

Arlinghaus R, Tillner R, Bork M. 2015. Explaining participation rates in recreational fishing across industrialised countries. Fisheries Management and Ecology 22(1), 45-55.

Baker R, et al. 2010. Research synthesis: AAPOR report on online panels. Public Opinion Quarterly 74(4), 711-781.

Beard TD, Arlinghaus R, Cooke SJ, McIntyre PB, De Silva S, Bartley D, Cowx IG. 2011. Ecosystem approach to inland fisheries: Research needs and implementation strategies. Biology Letters 7(4), 481483.

Bolstad GH, et al. 2017. Gene flow from domesticated escapes alters the life history of wild Atlantic salmon. Nature Ecology \& Evolution 1, 0124.

Bolster WJ. 2008. Putting the ocean in Atlantic history: maritime communities and marine ecology in the Northwest Atlantic, 1500-1800. The American Historical Review 113(1), 19-47.

Borch T, Aas $\varnothing$, Policansky D. 2008. International fishing tourism: past, present and future. Pages 268-291 in Aas $\varnothing$, editor. Global challenges in recreational fisheries. Blackwell Publishing Ltd, Oxford, United Kingdom.

This is the peer reviewed version of the following article: Kochalski, Sophia; Riepe, Carsten; Fujitani, Marie; Aas, Øystein; Arlinghaus, Robert. Public perception of river fish biodiversity in four European countries. Conservation Biology 2018 s. 1-12 which has been published in final form at 10.1111/cobi.13180. This article may be used for noncommercial purposes in accordance with Wiley Terms and Conditions for Use of Self-Archived Versions. 
Bremner A, Park K. 2007. Public attitudes to the management of invasive non-native species in Scotland. Biological Conservation 139(3), 306-314.

Carrizo SF, Jähnig SC, Bremerich V, Freyhof J, Harrison I, He F, Langhans SD, Tockner K, Zarfl C, Darwall W. 2017. Freshwater megafauna: Flagships for freshwater biodiversity under threat. BioScience 67(10), 919-927.

Chaput G. 2012. Overview of the status of Atlantic salmon (Salmo salar) in the North Atlantic and trends in marine mortality. ICES Journal of Marine Science 69(9), 1538-1548.

Closs GP, Angermeier PL, Darwall WR, Balcombe SR. 2015. Why are freshwater fish so threatened?

Pages 37-75 in Closs GP, Krkosek M, Olden J, editors. Conservation of freshwater fishes. Cambridge University Press, Cambridge, United Kingdom.

Cooke SJ, Lapointe NWR, Martins EG, Thiem JD, Raby GD, Taylor MK, Beard TD, Cowx IG. 2013. Failure to engage the public in issues related to inland fishes and fisheries: strategies for building public and political will to promote meaningful conservation. Journal of Fish Biology 83(4), 997-1018.

Darwall W, Smith K, Allen D, Holland R, Harrison I, Brooks E. 2011. The diversity of life in African freshwaters: underwater, under threat: an analysis of the status and distribution of freshwater species throughout mainland Africa. Cambridge University Press, Cambridge, United Kingdom.

Dudgeon D, et al. 2006. Freshwater biodiversity: importance, threats, status and conservation challenges. Biological Reviews 81(2), 163-182.

Eder K. 1996. Theory, culture \& society. The social construction of nature: A sociology of ecological enlightenment (M. Ritter, Trans.). Sage Publications, Thousand Oaks, California.

Eurostat. 2015. Census data for the online populations. European Commission, Luxembourg. Available from http://ec.europa.eu/eurostat/de/data/database (accessed April 2018).

This is the peer reviewed version of the following article: Kochalski, Sophia; Riepe, Carsten; Fujitani, Marie; Aas, $\emptyset$ ystein; Arlinghaus, Robert. Public perception of river fish biodiversity in four European countries. Conservation Biology 2018 s. 1-12 which has been published in final form at 10.1111/cobi.13180. This article may be used for noncommercial purposes in accordance with Wiley Terms and Conditions for Use of Self-Archived Versions. 
Eurostat. 2016. Information on internet penetration. European Commission, Luxembourg. Available from http://ec.europa.eu/eurostat/statistics-explained/index.php/Digital_economy_and_society_ statistics_-_households_and_individuals (accessed April 2018).

ESOMAR (European Society for Opinion and Market Research), GRBN (Global Research Business Network). 2015. Guideline for conducting online research. ESOMAR, Amsterdam, GRBN, New York. Available from https://www.esomar.org/uploads/public/knowledge-and-standards/codes-and-guidelines/ESOMARGRBN-Online-Research-Guideline-October-2015.pdf (accessed April 2018).

EUMOFA (European Market Observatory for Fisheries and Aquaculture Products). 2017. EU Consumer habits regarding fishery and aquaculture products. Final Report. European Commission, Luxembourg.

Freyhof J, Brooks E. 2011. European red list of freshwater fishes. Publications office of the European Union, Luxembourg.

Fujitani M, McFall A, Randler C, Arlinghaus R. 2017. Participatory adaptive management leads to environmental learning outcomes extending beyond the sphere of science. Science Advances, 3(6), e1602516.

Gelcich S, Buckley P, Pinnegar JK, Chilvers J, Lorenzoni I, Terry G, Guerrero M, Castilla JC, Valdebenito A, Duarte CM. 2014. Public awareness, concerns, and priorities about anthropogenic impacts on marine environments. Proceedings of the National Academy of Sciences 111(42), 15042-15047.

Gozlan RE, Britton JR, Cowx I, Copp GH. 2010. Current knowledge on non-native freshwater fish introductions. Journal of Fish Biology 76(4), 751-786.

Groves RM, Fowler Jr FJ, Couper MP, Lepkowski JM, Singer E, Tourangeau R. 2011. Survey methodology (Vol. 561). John Wiley \& Sons, Hoboken, New Jersey.

Hanley N, Wright RE, Adamowicz V. 1998. Using choice experiments to value the environment. Environmental and Resource Economics 11(3), 413-428.

This is the peer reviewed version of the following article: Kochalski, Sophia; Riepe, Carsten; Fujitani, Marie; Aas, $\varnothing$ ystein; Arlinghaus, Robert. Public perception of river fish biodiversity in four European countries. Conservation Biology 2018 s. 1-12 which has been published in final form at 10.1111/cobi.13180. This article may be used for noncommercial purposes in accordance with Wiley Terms and Conditions for Use of Self-Archived Versions. 
Hein L, Van Koppen K, De Groot RS, Van lerland EC. 2006. Spatial scales, stakeholders and the valuation of ecosystem services. Ecological economics 57(2), 209-228.

Heino J, Erkinaro J, Huusko A, Luoto M. 2015. Climate change effects on freshwater fishes, conservation and management. Pages 76-106 in Closs GP, Krkosek M, Olden J, editors. Conservation of freshwater fishes. Cambridge University Press, Cambridge, United Kingdom.

ICC (International Chamber of Commerce), ESOMAR (European Society for Opinion and Market Research). 2016. International code on market, opinion and social research and data analytics. ICC, France, ESOMAR, Amsterdam. Available from https://www.esomar.org/uploads/public/knowledge-andstandards/codes-and-guidelines/ICCESOMAR_Code_English_.pdf (accessed April 2018).

Inglehart R. 1990. Culture shift in advanced industrial society. Princeton University Press, Princeton, New Jersey.

Inglehart R. 1997. Modernization and postmodernization: Cultural, economic, and political change in 43 societies. Princeton University Press, Princeton, New Jersey.

Jelks HL, et al. 2008. Conservation status of imperiled North American freshwater and diadromous fishes. Fisheries 33(8), 372-407.

Kalinkat G, et al. 2017. Flagship umbrella species needed for the conservation of overlooked aquatic biodiversity. Conservation Biology 31(2), 481-485.

Kansky R, Knight AT. 2014. Key factors driving attitudes towards large mammals in conflict with humans. Biological Conservation 179, 93-105.

Klöckner CA. 2013. A comprehensive model of the psychology of environmental behaviour - A metaanalysis. Global Environmental Change 23(5), 1028-1038.

Kollmuss A, Agyeman J. 2002. Mind the gap: why do people act environmentally and what are the barriers to pro-environmental behavior?. Environmental Education Research 8(3), 239-260.

This is the peer reviewed version of the following article: Kochalski, Sophia; Riepe, Carsten; Fujitani, Marie; Aas, $\varnothing$ ystein; Arlinghaus, Robert. Public perception of river fish biodiversity in four European countries. Conservation Biology 2018 s. 1-12 which has been published in final form at 10.1111/cobi.13180. This article may be used for noncommercial purposes in accordance with Wiley Terms and Conditions for Use of Self-Archived Versions. 
Manfredo, MJ. 2008. Who cares about wildlife? Springer, New York. Manfredo MJ, et al. 2017. Why

social values cannot be changed for the sake of conservation. Conservation Biology 31(4):772-780.

Miller JR. 2005. Biodiversity conservation and the extinction of experience. Trends in Ecology \&

Evolution 20(8), 430-434.

Monroe JB, Baxter CV, Olden JD, Angermeier PL. 2009. Freshwaters in the public eye: Understanding the role of images and media in aquatic conservation. Fisheries 34(12), 581-585.

Olsen MS, Osmundsen TC. 2017. Media framing of aquaculture. Marine Policy, 76, 19-27.

Osbaldiston R, Schott JP. 2012. Environmental sustainability and behavioral science: Meta-analysis of pro-environmental behavior experiments. Environment and Behavior 44(2), 257-299.

Pimm SL, Jenkins CN, Abell R, Brooks TM, Gittleman JL, Joppa LN, Raven PH, Roberts CM, Sexton JO. 2014. The biodiversity of species and their rates of extinction, distribution, and protection. Science 344(6187), 1246752.

Potts T, Pita C, O'Higgins T, Mee L. 2016. Who cares? European attitudes towards marine and coastal environments. Marine Policy 72, 59-66.

Rathwell K, Armitage D. 2016. Art and artistic processes bridge knowledge systems about social- ecological change: An empirical examination with Inuit artists from Nunavut, Canada. Ecology and Society 21(2).

Reinhard W. 2008. The SANDOZ Catastrophe and the consequences for the River Rhine. Pages 113-121 in Apostol I, Coldewey WG, Barry DL, Reimer D, editors. Risk assessment as a basis for the forecast and prevention of catastrophies. IOS Press, Amsterdam, the Netherlands.

Riepe C, Arlinghaus R. 2014. Einstellungen der Bevölkerung in Deutschland zum Tierschutz in der Angelfischerei. Berichte des IGB, Heft 27. Leibniz-Institut für Gewässerökologie und Binnenfischerei (IGB) im Forschungsverbund Berlin e.V, Berlin.

This is the peer reviewed version of the following article: Kochalski, Sophia; Riepe, Carsten; Fujitani, Marie; Aas, $\emptyset$ ystein; Arlinghaus, Robert. Public perception of river fish biodiversity in four European countries. Conservation Biology 2018 s. 1-12 which has been published in final form at 10.1111/cobi.13180. This article may be used for noncommercial purposes in accordance with Wiley Terms and Conditions for Use of Self-Archived Versions. 
determines the behavioral intention of local-level fisheries managers to alter fish stocking practices in freshwater recreational fisheries of two European countries?. Fisheries Research 194, 173-187.

Schwartz SH. 2006. A theory of cultural value orientations: Explication and applications. Comparative Sociology 5(2), 137-182.

Schwartz SH. 2012. An overview of the Schwartz theory of basic values. Online readings in Psychology and Culture 2(1), 11.

Steg L., Vlek C. 2009. Encouraging pro-environmental behaviour: An integrative review and research agenda. Journal of Environmental Psychology 29(3), 309-317.

Stern PC. 2000. Psychology and the science of human-environment interactions. American Psychologist 55(5), 523-530.

Stern PC. 2005. New environmental theories: toward a coherent theory of environmentally significant behavior. Journal of Social Issues 56(3), 407-424.

Walker-Springett K, Jefferson R, Böck K, Breckwoldt A, Comby E, Cottet M, Hübner G, LeLay YF, Shaw S, Wyles K. 2016. Ways forward for aquatic conservation: applications of environmental psychology to support management objectives. Journal of Environmental Management 166, 525-536.

Weber EU. 2010. What shapes perceptions of climate change? Wiley Interdisciplinary Reviews: Climate Change 1(3), 332-342.

Wolter C. 2015. Historic catches, abundance, and decline of Atlantic salmon Salmo salar. Aquatic Sciences 77(3), 367-380.

Wolter C, Röhr F. 2010. Distribution history of non-native freshwater fish species in Germany: how invasive are they? Journal of Applied Ichthyology 26(s2), 19-27.

This is the peer reviewed version of the following article: Kochalski, Sophia; Riepe, Carsten; Fujitani, Marie; Aas, $\varnothing$ ystein; Arlinghaus, Robert. Public perception of river fish biodiversity in four European countries. Conservation Biology 2018 s. 1-12 which has been published in final form at 10.1111/cobi.13180. This article may be used for noncommercial purposes in accordance with Wiley Terms and Conditions for Use of Self-Archived Versions. 
Table SI1: Overview of sample characteristics ( $n=1.000$ per country). Differences between countries in the age distribution were tested for significance $(p<0.05)$ with the Kruskal-Wallis test. Distribution of gender and educational levels were tested for differences with Pearson's chi-squared tests.

\begin{tabular}{|c|c|c|c|c|c|c|c|}
\hline \multirow{3}{*}{ Gender (in \%) } & \multirow{3}{*}{$\begin{array}{l}\text { female } \\
\text { male }\end{array}$} & \multirow{2}{*}{$\begin{array}{r}\text { Germany } \\
48.4\end{array}$} & \multirow{2}{*}{$\begin{array}{r}\text { France } \\
48.9\end{array}$} & \multirow{2}{*}{$\begin{array}{r}\text { Norway } \\
47.5\end{array}$} & \multirow{2}{*}{$\begin{array}{r}\text { Sweden } \\
47.7\end{array}$} & \multicolumn{2}{|c|}{ Test statistic (df) } \\
\hline & & & & & & $\chi^{2}$ & $0.5(3)$ \\
\hline & & 51.6 & 51.1 & 52.5 & 52.3 & & \\
\hline \multicolumn{2}{|c|}{ Mean age in years (SE) } & $43.1(0.5)$ & $41.5(0.5)$ & $42.3(0.5)$ & $43.2(0.5)$ & $H$ & $7.7(3)$ \\
\hline \multirow[t]{3}{*}{ Education a (in \%) } & $\operatorname{low}(0-2)$ & 11.1 & 17.8 & 18.4 & 18.2 & $\chi^{2}$ & $94.3(6) *$ \\
\hline & medium (3 - 4) & 59.0 & 45.6 & 38.6 & 44.1 & & \\
\hline & high (5 - 8) & 29.9 & 36.6 & 43.0 & 37.7 & & \\
\hline
\end{tabular}

a According to UIS (UNESCO Institute for Statistics). 2012. International standard classification of education: ISCED 2011. UNESCO-UIS, Montreal.

$* p$-value $<0.001$

Table SI2: Mean (SD) importance of harmony with nature as a guiding principle in life measured with three items from the Schwartz value scale (Cronbach's alpha $\mathbf{0 . 8 9}$ ) on a 5-point scale from 1 (not at all important) to 5 (very important). Differences between countries were tested for significance with the Kruskal-Wallis test $(H=75.3, p<0.001)$.

\begin{tabular}{lrrrr}
\hline & Germany & France & Norway & Sweden \\
\hline $\begin{array}{l}\text { Harmony with nature } \\
\text { Scale items }\end{array}$ & $3.9^{\mathrm{ab}}(0.9)$ & $3.8^{\mathrm{b}}(0.9)$ & $3.6^{\mathrm{c}}(0.9)$ & $3.9^{\mathrm{a}}(0.9)$ \\
$\quad \begin{array}{l}\text { Respecting the earth, living in harmony with other } \\
\quad \text { animal and plant species }\end{array}$ & $4.1(0.8)$ & $3.9(0.9)$ & $3.7(0.9)$ & $4.0(0.9)$ \\
$\begin{array}{l}\text { Protecting the environment, preserving nature } \\
\text { Unity with nature, fitting into nature }\end{array}$ & $4.0(0.8)$ & $3.9(0.9)$ & $3.9(0.9)$ & $4.0(0.9)$ \\
\hline$\quad$ Number of observations & $3.6(1.0)$ & $3.7(1.0)$ & $3.3(1.0)$ & $3.7(1.0)$ \\
\hline
\end{tabular}

$\overline{a, b, c}$ Any two means in a row that do not share a letter are significantly different $(p<0.05)$ according to pairwise comparisons using the Tukey- Kramer (Nemenyi) test

This is the peer reviewed version of the following article: Kochalski, Sophia; Riepe, Carsten; Fujitani, Marie; Aas, $\varnothing$ ystein; Arlinghaus, Robert. Public perception of river fish biodiversity in four European countries. Conservation Biology 2018 s. 1-12 which has been published in final form at 10.1111/cobi.13180. This article may be used for noncommercial purposes in accordance with Wiley Terms and Conditions for Use of Self-Archived Versions. 
Table SI3: Recreational activities that respondents (in \%) indicated to have had performed in the 12 months prior to the survey, multiple answers were possible. Differences between countries were tested for significance with Pearson's chi-squared test (activities) and one-way ANOVA (number of activities per person).

\begin{tabular}{|c|c|c|c|c|c|c|}
\hline Activity & Germany & France & Norway & Sweden & $x^{2}$ & $p$ \\
\hline $\begin{array}{l}\text { Moving around, on or near the banks (e.g., } \\
\text { taking a walk, jogging) }\end{array}$ & $66.5^{a}$ & $49.5^{c}$ & $69.6^{a}$ & $59.0^{\mathrm{b}}$ & 101.5 & $<0.001$ \\
\hline Bathing, swimming & $50.6^{b}$ & $61.8^{a}$ & $49.4^{b}$ & $59.0^{\mathrm{a}}$ & 45.8 & $<0.001$ \\
\hline $\begin{array}{l}\text { Staying on the beach or on the banks (e.g., } \\
\text { lying in the sun) }\end{array}$ & 54.3 & 53.9 & 58.1 & 53.4 & 5.5 & 0.133 \\
\hline $\begin{array}{l}\text { Observing plants or animals near or on the } \\
\text { water }\end{array}$ & $28.9^{b}$ & $37.2^{\mathrm{a}}$ & $38.5^{\mathrm{a}}$ & $32.8^{\mathrm{b}}$ & 25.5 & $<0.001$ \\
\hline Angling, fishing & $4.6^{c}$ & $18.2^{\mathrm{b}}$ & $28.6^{\mathrm{a}}$ & $27.3^{a}$ & 232.2 & $<0.001$ \\
\hline Going on a cruise ship / on a tourist boat & $26.4^{a}$ & $12.7^{c}$ & $13.8^{\mathrm{bc}}$ & $16.6^{b}$ & 81.4 & $<0.001$ \\
\hline Navigating a motorboat & $4.4^{c}$ & $12.7^{b}$ & $22.1^{\mathrm{a}}$ & $15.4^{\mathrm{b}}$ & 136.4 & $<0.001$ \\
\hline Camping near the waterside & $11.1^{\mathrm{b}}$ & $12.7^{b}$ & $17.6^{\mathrm{a}}$ & $8.4^{c}$ & 40.9 & $<0.001$ \\
\hline $\begin{array}{l}\text { Navigating a pleasure boat without an } \\
\text { engine (e.g., sailing, surfing, rowing, } \\
\text { kayaking) }\end{array}$ & $7.5^{b}$ & $13.8^{\mathrm{a}}$ & $13.5^{\mathrm{a}}$ & $15.0^{\mathrm{a}}$ & 30.8 & $<0.001$ \\
\hline Winter sports (e.g., ice skating) & $4.4^{c}$ & $11.3^{\mathrm{b}}$ & $15.5^{\mathrm{a}}$ & $10.3^{\mathrm{b}}$ & 67.3 & $<0.001$ \\
\hline Diving, snorkeling & $5.2^{\mathrm{b}}$ & $10.7^{a}$ & $6.5^{\mathrm{b}}$ & $6.1^{\mathrm{b}}$ & 27.3 & $<0.001$ \\
\hline Hunting near the water (e.g., water fowl) & $0.1^{\mathrm{b}}$ & $2.0^{\mathrm{a}}$ & $2.4^{\mathrm{a}}$ & $1.9^{\mathrm{a}}$ & 19.8 & $<0.001$ \\
\hline Number of activities per person & $2.6^{c}$ & $3.0^{\mathrm{b}}$ & $3.4^{a}$ & $3.1^{\mathrm{b}}$ & $\boldsymbol{F}$ & $<0.001$ \\
\hline (mean \pm standard deviation) & (1.7) & (2.5) & (2.3) & (2.1) & 18.6 & \\
\hline Number of observations & 998 & 996 & 998 & 993 & & \\
\hline
\end{tabular}

${ }^{a, b, c, d}$ Any two means in a row that do not share a letter are significantly different $(p<0.05)$ according to post hoc pairwise comparisons with Pearson's chi-squared test (activities) or according to Tukey's range test (number of activities per person).

This is the peer reviewed version of the following article: Kochalski, Sophia; Riepe, Carsten; Fujitani, Marie; Aas, Øystein; Arlinghaus, Robert. Public perception of river fish biodiversity in four European countries. Conservation Biology 2018 s. 1-12 which has been published in final form at 10.1111/cobi.13180. This article may be used for noncommercial purposes in accordance with Wiley Terms and Conditions for Use of Self-Archived Versions. 
Table SI4: Wording and order of the survey questions underlying the study results.

Part of the survey

Survey introduction

(2015)

\section{Wording in the survey}

Dear participant. Thank you very much for participating in this survey on the topic "HumansRivers-Species Diversity in <INSERT COUNTRY NAME >"! This survey is conducted on behalf of $<$ INSERT NAME DEPENDING ON COUNTRY>. Your answers will help provide politics and science with a planning guide for the management of our rivers taking the interests of the citizens into consideration. The survey does not serve any commercial interests. Your answers will be kept strictly confidential and any results will be reported anonymously.

\begin{tabular}{l}
\hline Age \\
\hline Gender \\
\hline Education \\
\hline Recreational activities \\
\\
\hline Familiarity with species \\
\hline Perceived native or \\
non-native origin of \\
fish species \\
\hline $\begin{array}{l}\text { Self-reported level of } \\
\text { feeling informed about } \\
\text { biodiversity in fishes }\end{array}$
\end{tabular}

What is your age?

What is your gender?

Which is your highest finished education level?

Which recreational activities related to inland water bodies have you pursued at least once in the last 12 months? We mean any activities related to lakes, rivers or streams excluding the sea and excluding artificially created very small water bodies such as garden ponds. Tick all activities that apply.

Which of these fish species have you heard of? Tick all that apply.

According to your opinion, which of these fish species are native to the inland waters of <INSERT COUNTRY NAME > and which are not? Native species have naturally colonized the waters in the past without human assistance. Mark your answer for all species shown.

Let's turn to the topic of biodiversity. Biodiversity denotes the diversity of all living organisms and their habitats including species diversity, the diversity of genes and populations of a given species in a region, and the diversity of ecosystems in terms of types of lakes, rivers etc. How informed do you feel about the topic of biodiversity in fishes? Tick one box only.

Beliefs about threats According to independent research, the earth's biodiversity is threatened by human impact. This is said to be true also for many rivers of <INSERT COUNTRY NAME $>$ and the fishes that are native to them. Here is a list with potential human-made causes for the loss of biodiversity of native fish species in the rivers of <INSERT COUNTRY NAME $>$. For each of them, indicate how strongly you believe the factor contributes to fish biodiversity loss. To the loss of native fish biodiversity in the rivers of $<$ INSERT COUNTRY NAME $>$, this factor makes ...

\begin{tabular}{|c|c|}
\hline $\begin{array}{l}\text { Self-reported level of } \\
\text { feeling informed about } \\
\text { the threats caused by } \\
\text { the introduction of } \\
\text { non-native fish species }\end{array}$ & $\begin{array}{l}\text { The intentional or accidental introduction of fish species by humans to rivers to which they were } \\
\text { originally not native can cause biodiversity loss of native fish species. Non-native fish species may, } \\
\text { for example, compete with native fish species and other aquatic animals for food and living space } \\
\text { or they may transmit diseases and parasites to native fishes or even interbreed with native } \\
\text { species. How informed do you feel overall about the potential threats caused by the introduction } \\
\text { of non-native fishes to the rivers of <INSERT COUNTRY NAME>? Tick one box only. }\end{array}$ \\
\hline Attitudes & $\begin{array}{l}\text { Now comes a list with statements related to the topic of fishes in the rivers of <INSERT COUNTRY } \\
\text { NAME }>\text {. All these statements express correct facts. How do you personally evaluate them? There } \\
\text { are no right or wrong answers, we are interested in your personal view. In my opinion, this is ... }\end{array}$ \\
\hline $\begin{array}{l}\text { Use and non-use value } \\
\text { of fish }\end{array}$ & $\begin{array}{l}\text { Please indicate the degree to which you agree or disagree with these statements about native fish } \\
\text { populations. }\end{array}$ \\
\hline Schwartz value scale & $\begin{array}{l}\text { Please indicate how important each of the following values is as a guiding principle in your life. As } \\
\text { a guiding principle in my life, this value is ... }\end{array}$ \\
\hline Open control question & $\begin{array}{l}\text { The survey is now over. How did you like it? Is there anything that you want to tell us about the } \\
\text { survey or the topics addressed in it? Any remarks or criticisms are more than welcome. }\end{array}$ \\
\hline Survey ending (2015) & $\begin{array}{l}\text { We might want to get in touch with you again for another survey about the topic of "Humans- } \\
\text { Rivers-Species Diversity in <INSERT COUNTRY NAME>" at the beginning of next year. For } \\
\text { participating, you would receive an additional bonus. Thank you very much for your patience and } \\
\text { cooperation! }\end{array}$ \\
\hline $\begin{array}{l}2016 \text { survey question } \\
\text { about salmon }\end{array}$ & $\begin{array}{l}\text { Thinking of rivers only, according to your opinion in which of these countries are salmon native } \\
\text { and in which are they not native? Native species have naturally colonized the waters in the past } \\
\text { without human assistance }\end{array}$ \\
\hline $\begin{array}{l}2016 \text { survey question } \\
\text { about Atlantic salmon }\end{array}$ & $\begin{array}{l}\text { Still thinking of rivers only, according to your opinion in which of these countries are Atlantic } \\
\text { salmon native and in which are they not native? Native species have naturally colonized the } \\
\text { waters in the past without human assistance }\end{array}$ \\
\hline
\end{tabular}

This is the peer reviewed version of the following article: Kochalski, Sophia; Riepe, Carsten; Fujitani, Marie; Aas, $\varnothing$ ystein; Arlinghaus, Robert. Public perception of river fish biodiversity in four European countries. Conservation Biology 2018 s. 1-12 which has been published in final form at 10.1111/cobi.13180. This article may be used for noncommercial purposes in accordance with Wiley Terms and Conditions for Use of Self-Archived Versions. 